\title{
A Study of the Effects of Non-Oil Exports on Iranian Economic Growth
}

\author{
Naser Ali Yadollahzadeh Tabari, Islamic Azad University \\ Mohammad Nasrollahi, Islamic Azad University
}

\begin{abstract}
This paper examines the effects of Iranian non-oil exports on output during the years 19802007. We use an augmented neoclassical production function type and apply VECM methodology to estimate the short and long-run effects. The results show: negative effects of non-oil export on non-Export output, while capital stock and labor force have positive effects on non-Export GDP.
\end{abstract}

JEL Codes: C12, C32.

\section{Introduction}

The relationship between exports and economic growth has been one of the interesting issues for economists in recent decades. The dominant view in the last two decades can be said to be inclined towards the acceptance of 'export-led growth'; however, since export is one of the components of gross domestic product (GDP), a positive correlation between these two variables is not entirely unexpected (Greenaway and Sapsford, 1994). But the advocates of this theory believe that export's aid to national output growth is not only due to increase in export quantity but also because of the creation of greater output capacities, economy of scale, aid to technological improvement and efficient resource allocation due to the pressure from foreign competition.

Export growth is able to provide the necessary basis for a rise in home investment, and also pave the way for greater levels of foreign investment. Moreover export growth also offers motivation for greater profitability whilst also providing cash flow for imports of intermediate and capital goods Fosu (1990). This process will ultimately lead to economic growth. Empirical studies regarding the relationship between exports and output growth can categorized in: (i) cross-sectional and (ii) time-series analysis.

Experimental studies on testing the 'export-led growth' hypothesis carried out in recent decades have not reached similar results and have sometimes been in complete contrast. Although the 'export-led growth' hypothesis is more accepted or supported than others, the short-term relationship between the two variables of export and economic growth has been mainly emphasized (Love, 1994 and Edwards, 1993). Some studies have even challenged the exogenous growth theory and questioned its accuracy for some developing countries (Love 1994, Greenaway and Stansford 1994). Some research work such as those carried out by Michaely (1977), Balassa (1978), Heler \& Porter (1978), Feder (1983), Kavoussi (1984), Ram (1985) and Fosu(1990) have supported the idea that export growth motivates economic growth. However, the strong relationship between export and economic growths does not imply their causality. These researchers assumed that there is a causal relationship between export and GDP growths. However some researchers questioned the results of cross-section studies (e.g. Sheehey (1990) and Pritchett (1996)). They believe the reliability and validity of the findings of cross-sectional studies is doubtful. In these studies, they implicitly assume that countries in question have a common economic structure and follow similar production technology (Shirizai and Manap, 2005). Moreover, the relationship between export and economic growth is a long-run phenomenon that cannot be fully captured by cross-sectional analysis. Using the analysis of time-series data instead of cross-section data is another way of studying causality.

A number of time-series researches were carried out in the 1980s and 1990s. Jung and 
Marshall (1985), Chow (1987), Hesiao (1987), Bahmani Oskooee et al (1991), Dodaro (1993) and Love (1994) are some of the main examples. Using Grenger (1969), Sims (1972) and Hisao's (1987) approach to the causality test, these researchers have not reached a single conclusion implying the 'export-led growth' hypothesis. Although some of them reached some evidence to support the mentioned hypothesis, they lack finality. While these studies found some evidence to support the 'export-led growth' hypothesis, their findings are far from conclusive.

Using Grenger's causality concept, Jung and Marshall (1985) concluded that the 'export-led growth' hypothesis is only supported in 4 of the 37 involved countries. Bahmani Oskooee, Mohtadi, and Shabsigh(1991) reached some evidence in support of the 'export-led growth' hypothesis through Grenger's causality, although these results lack adequate finality. Love(1994) also studied the two motives of growth hypothesis, namely export and the government sector for economic growth through combining Grenger's causality with FPE. He used Heler and Porter's approach (1978) in defining non-export GDP and reached weak evidence in support of the idea that export and government expenditure motivate growth. Using Grenger's approach, Dodaro (1993) studied causality for a larger group including 87 countries but did not reach decisive results showing that export growth motivates GDP growth. However, support for the effect of GDP growth on export growth was also weak, although stronger than previous ones.

On the other hand, some researchers used Sim's approach (1972) to study causality. Using this approach, Chow(1987) studied the causality between export growth and manufactured output growth. He reached the following results: the presence of bilateral causality in Brazil, Hong Kong, Israel, Korea, Singapore and Taiwan; the presence of unilateral causality from export growth to output growth in Mexico; and the lack of causality in Argentina. However, it should be noted that Sim's procedure has the disadvantage that it uses a higher degree of freedom compared to Grenger's test since it includes lead values of a variable in the model(Love and Chandra, 2005).

One of the basic weaknesses of traditional causality studies whether in Grenger's approach (1969) or Sim's (1972) is that they do not examine the co integration properties of time-series variables like exports and GDP. As Grenger (1988) mentioned, if time series are co integrated, traditional causality tests may reach wrong conclusions on causality. Using Engle and Granger's two-step approach (1987) to co-integration and error correction modeling and using quarterly data instead of annul data for 8 studied countries, Bahmani Oskooee and Ales (1993) reached strong experimental evidence for two-way causality between export and GDP growths in 8 out of 9 countries.

\section{Materials and Methods}

The main purpose of this research is to study the long-run relationship between growth and export. In this regard some issues are noticeable; firstly, the time series techniques were used due to cross-section regression limitations; secondly, we used augmented production function including export instead of two-variable causal relationship in order to avoid probable misspecification; thirdly, we divided export into oil and non-oil in order to establish a more precise study of the effects of export on growth( There is a considerable difference between the share of oil and non-oil export in Iran's GDP). According to above-mentioned theoretical and methodological arguments, we use a neoclassical production function:

$$
\mathrm{Y}_{\mathrm{t}}=\mathrm{A}_{\mathrm{t}} \mathrm{L}_{\mathrm{t}}^{\alpha} \mathrm{K}_{\mathrm{t}}^{\beta}
$$

Where $\mathrm{Y}$ is aggregate real output, and $\mathrm{A}, \mathrm{L}$ and $\mathrm{K}$ are the level of total factor productivity, labor force and capital stock respectively. Because we want to investigate if and how non-oil exports affect economic growth through increase in productivity, we assume that the total 
productivity of factors is a function of non-oil export and other exogenous factors, $c_{t}$.

$$
A_{t}=f\left(N O X_{t}, C_{t}\right)=\mathrm{C}_{\mathrm{t}} N O X_{t}^{\delta}
$$

Inserting equation (2) into equation (1), we will have:

$$
\mathrm{Y}_{\mathrm{t}}=\mathrm{C}_{\mathrm{t}} \mathrm{L}_{\mathrm{t}}^{\alpha} \mathrm{K}_{\mathrm{t}}^{\beta} N O X_{t}^{\delta}
$$

Where $\boldsymbol{\alpha} \boldsymbol{\beta}$ and $\boldsymbol{\delta}$ are the elasticity of production with respect to L, K and NOX. We will reach the following estimated linear function by taking the natural logs (L) of both sides of the equation (3):

$$
\mathrm{LY}_{\mathrm{t}}=\mathrm{c}+\alpha \mathrm{LL}_{\mathrm{t}}+\beta \mathrm{LK}_{\mathrm{t}}+\delta \mathrm{L} N O X_{t}+e_{t}
$$

In which all coefficients are constant elasticity, $\mathrm{c}$ is a constant parameter, and $\boldsymbol{e}_{\boldsymbol{t}}$ is the error term which reflects the influence of all the other factors. Therefore, the estimation of $\boldsymbol{\delta}$ measures the effects of non-oil exports productivity on economic growth. However, the problem is that non-oil export- via the national accounting identity- is itself a component of output. Hence, even if there is no positive effect of non-oil export on TFP in the economy, a positive and significant correlation between the exports and aggregate output is inevitable since rapid increase in exports automatically leads to higher GDP growth (Herzer et al, 2003). To remedy this problem, it is necessary to separate the 'economic influence' of exports on output from the influence incorporated 'growth accounting relationship'. For this purpose, we use the net aggregate output of the non-oil export, NXY (NXY=Y-NOX) instead of total output, Y. We will reach the following equation by replacing $\mathrm{Y}$ with $\mathrm{NXY}$ :

$$
\mathrm{LNXY}_{\mathrm{t}}=\mathrm{c}+\alpha \mathrm{LL}_{\mathrm{t}}+\beta \mathrm{LK}_{\mathrm{t}}+\boldsymbol{\delta} \mathrm{LNOX_{t }}+e_{t}
$$

This equation is estimated to determine the impact of increasing non-oil export on economic growth via increases in productivity. However, it should be noted that higher rates of capital formation, labor force growth and non-oil export growth can themselves be due to higher output growth. We will investigate this causal relationship in an empirical analysis using VAR approach.

\section{Results}

This study aims at testing the presence of a long-term relation between involved research variables and also estimating regression model coefficients presented above. Accordingly, needed annual data for the period 1980-2007 was collected from statistics published by IRI Central Bank and Management and Planning Organization. However, it should be noted that monetary variables used in this research (K, NOX. NXY) are evaluated in Iranian Rials at 1997 constant prices.

In the first step we test the variables for unit roots to verify their order of integration. The Augmented Dickey-Fuller (ADF) test was used to determine the integration degree of involved variables. Table (1) shows the results of unit root tests for the variables. 


\begin{tabular}{rcc}
\hline Variable & Levels & First differences \\
\hline LL & $1.62-$ & $* 5.29-$ \\
LK & 1.97 & $* 4.78-$ \\
LNOX & $2.68-$ & $* 5.80-$ \\
LNXY & 2.54 & $* 5.42-$
\end{tabular}

Table 1- ADF tests for unit roots. Note: The critical values of the tests are taken from MacKinnon (1994). The asterisk (*) indicates that the test statistic is significant at 5 percent level.

The results of these tests reveal that all variables are non-stationary in level while all their first- differences are stationary. Thus, all level variables are I(1) since the first- differences are $\mathrm{I}(0)$. In applying Johanson's procedure there is a need to consider two important issues. The first is determining the appropriate lag length, $\mathrm{K}$, of the VAR model that is considered to be $\mathrm{P}=4$ according to LR standard. Then, it is necessary to study the number of co-integrated vectors along with the presence of deterministic components (constant and trend) in the cointegration space. An important aspect of the VECM includes inserting both the levels and differences of variables into the model. The asymptotic distribution of the co-integration test is dependent on the assumption of deterministic components in a given model. The selection between the different models is practically limited to the three following cases: model 2, including intercept in the cointegration relation, model 3 including the presence of deterministic trends in levels (but neither nor an intercept is present in cointegration relation), and model 4 including a trend in the cointegration space. The Pantola principle can be used to choose one model among the three (Ousterio, 2007). Table (2) presents Pantola principle on the basis of Trace statistics and maximum eigenvalue test statistic to choose the appropriate model.

In these conditions, Trace test signifies the presence of one cointegration vector while the maximum eigenvalue test shows the presence of two long-run equilibrium relations between the variables of the system with intercept and no trend (model 3); therefore, the results of trace and maximum eigenvalue tests are different from each other. Cheung and Lie (1993) point out that the Trace test is more robust to both skewness and excess kurtosis in the residuals than the maximal eigenvalue test.

Trace Statistics

\begin{tabular}{cccc}
\hline$r$ & Model 2 & Model 3 & Model 4 \\
\hline 0 & $(\mathbf{5 4 . 0 8 ) 9 7 . 3 8}$ & $(47.86) 67.71$ & $(\mathbf{6 3 . 8 8 ) 1 0 9 . 9 6}$ \\
1 & $(35.19) 47.80$ & $(\mathbf{2 9 . 8 0 ) 2 2 . 9 4}$ & $(\mathbf{4 2 . 9 2 ) 6 1 . 5 1}$ \\
2 & $(\mathbf{2 0 . 2 6 ) 2 9 . 2 3}$ & $(\mathbf{1 5 . 4 9 ) 1 . 2 7}$ & $(\mathbf{2 5 . 8 7 ) 2 1 . 6 4}$ \\
\hline$r$ & \multicolumn{2}{c}{ Maximal Eigenvalue Statistics } & \\
\hline 0 & $(\mathbf{2 8 . 5 9 ) 4 9 . 5 7}$ & Model 3 & Model 4 \\
\hline 1 & $(\mathbf{2 2 . 3 0 ) 2 5 . 5 8}$ & $(\mathbf{2 7 . 5 8 ) 4 4 . 7 7}$ & $(\mathbf{3 2 . 1 2 ) 4 8 . 4 6}$ \\
2 & $(\mathbf{1 5 . 8 9 ) 2 1 . 4 9}$ & $(\mathbf{2 1 . 1 3 ) 2 1 . 6 6}$ & $(\mathbf{2 5 . 8 2 ) 3 9 . 8 7}$ \\
\hline
\end{tabular}

Note: $\mathrm{r}$ is the cointegration rank or the number of cointegrating vectors. Figures in the. parenthesis are the $95 \%$ critical values of the respective test statistics 
Hence, in view of its better properties and given present economic theories, we estimate VECM with model 3 with one cointegration vector.

After determining the number of co-integration vectors, the estimation of the long-run vector involved in the research (normalized on non-export output) is presented in table (3) with regard to theoretical literature.

\begin{tabular}{rccc}
\hline \multicolumn{1}{l}{ Variable } & Estimated Coefficient & LR Statistic & Probability \\
\hline LL & 0.65 & 8.65 & 0.003 \\
LK & 0.53 & 18.82 & 0.000 \\
LNOX & $0.04-$ & 12.97 & 0.000 \\
\hline
\end{tabular}

Note: The restricted cointegrating vector (LNXY-0.65LL-0.53LK+0.04LNOX) is .obtained after normalisation, i.e. after putting the coefficient of LNXY $=1$

\section{Table 3- Results of Long-run Vector Estimates}

As one can see in the above table, both labor force and capital stock variables have positive effects on GDP excluding non-oil export (NXY as dependent variables) while non-oil export has a negative effect on the dependent variable. The question whether above explanatory variables should be entered into the long-term vector related to NXY (GDP excluding non-oil export) can be answered by looking at the likelihood ratio test statistic (LR) which is distributed $\mathcal{X}^{2}$ with $\mathrm{r}$ degree of freedom. The test statistic for NXY are highly significant and thus, it is concluded that LL, LK, and NOX enter into a long-run equilibrium relationship with NXY.

Using error correction coefficients and short-run parameters, the method of how to adjust the variables towards equilibrium can be presented. We used the weak exagenity test in order to determine whether variables in the model are able to push GDP excluding non-oil export(NXY) towards their long-run equilibrium trend. Present adjustment coefficients in error correction model (presented in table 4) show that only changes in GDP excluding non-oil export (NXY) can restore the model to equilibrium in case of deviation from the long-run relation. The estimated model passes diagnostic tests and indicates that the model is fairly stable during the sample period.

\begin{tabular}{rccc}
\hline Variable & Estimated Coefficient & LR Statistic & Probability \\
\hline LL & $0.11-$ & 0.41 & 0.52 \\
LK & $0.18-$ & 1.49 & 0.22 \\
LNOX & $4.95-$ & 0.60 & 0.44 \\
LNXY & $2.64-$ & 23.06 & 0.00 \\
\hline
\end{tabular}

Table 4- Results of ECM Coefficient Vector Estimates

\section{Conclusion}

This paper uses annual time series data from 1980 through 2007 to investigate the relationship between exports and growth. Our findings, based on using Johnson's multivariable approach to co-integration, show that labor force, capital stock, non-oil export and GDP excluding non-oil export are co-integrated in Iran i.e. there is a long-run relationship between these variables. Moreover, the results of estimating long-run coefficients indicate that the coefficient related to labor force and capital stock is, according to theoretical expectations, completely positive and significant. Results also show that the coefficient related to non-oil 
export is, unexpectedly, negative and statistically significant. It means that the rise in non-oil export in Iran's economy decreases economic growth. This probably implies that the rise in non-oil export in Iran's economy leads to decline in total factor productivity and lessens the positive effect of other factors on economic growth. As also Griffin (1989) confirms this fact through regarding the relationship between export and economic growth to be too weak in developing countries even in best conditions and that we can expect export growth to be provide motives for overall economic progress only if there are well-developed relations between export and non-export sectors. In addition, the positive effect of export on overall economic growth is not initiated unless minimum progress level and strong intersectional relations in economy are established. However, it should be considered that the development of manufactured goods probably has more positive and reliable effects on economic growth.

\section{References}

- $\quad$ Asteriou, D. and S. G. Hall, 2007. Applied Econometrics A Modern Approach Using Eviews and Microfit. Palgrave Macmillan.

- Bahmani-Oskooee, M., and J. Alse, 1993. "Export growth and economic growth: An pplication of cointegration and error-correction modeling". Journal of Developing Areas, 27(7): 535-542.

- Bahmani-Oskooee, M., H. Mohtadi, , and G. Shabsigh, 1991. "Exports, growth and causality in LDCs: A reexamination". Journal of Development Economics, 36(October), 405-415.

- Balassa, B. 1978. "Exports and growth: Further evidence". Journal of Development Economics, 5(2): 181-189.

- Cheung, Y. W., \& K. S. Lai,., 1993." Finite sample sizes of Johansen's likelihood ratio tests for cointegration". Oxford Bulletin of Economics and Statistics, 55, 313328.

- Chow, P. C. Y. 1987. "Causality between export growth and industrial development: Empirical evidence from the NICs", Journal of Development Economics, 26, 1 (6): 55-63.

- Dodaro, S. 1993. "Export and growth: A reconsideration of causality". Journal of Developing Areas, 27(1): 227-244.

- Enders, W., 2004. Applied Econometrics Time Series. John Wiley \& Sons. New York.

- $\quad$ Engle, R. F., and C. W. J. Granger, 1987. "Cointegration and error correction: Representation, estimation and testing". Econometrica, 55(3): 251-276.

- $\quad$ Feder, G. 1983." On exports and economic growth". Journal of Development Economics, 5, 59-73.

- Fosu, A. K. 1990. " Exports and economic growth: The African case". World Development, 18,6 (6): 831-35.

- $\quad$ Granger, C.W.J., 1969." Investigating causal relations by econometric models and cross- spectral methods". Econometrica, 37, 424-438.

- Granger, C.W.J. (1988)." Some recent developments in a concept of causality". Journal of Econometrics, 39, 199-211.

- Greenaway, D. and D. Sapsford (1994). What does Liberalisation do for Exports and Growth?

- Weltwirtschaftliches Archiv 130 (1): 152-74.

- Griffin, K., 1989. Alternative Strategy for Economic Development, London, Macmillan Academic and Professional L.T.D. 
- Heller, P. S., and R. C. Porter, 1978. "Exports and growth: An empirical reinvestigation". Journal of Development Economics, 5, 191-193.

- Hsiao, M.W. 1987. "Tests of causality and exogeneity between export growth and economic growth". Journal of Development Economics, 18, 143-159.

- Jung, W. S. and P. J. Marshall, 1985. "Exports, growth and causality in developing countries". Journal of Development Economics, 18, 1 (4/5): 1-12.

- $\quad$ Kavoussi, R. M., 1984." Export expansion and economic growth: Further empirical evidence". Journal of Development Economics, 14, 1/2 (1/2): 241-50.

- Love, J., 1994." Engines of growth: The exports and government sectors". World Economy, 17, 203-218.

- $\quad$ Love, J., \& R. Chandra, 2005." Testing export-led growth in Bangladesh in a multivarate VAR framework". Journal of Asian Economics, 15, 1155-1168.

- Michaely, M., 1977. "Exports and growth: An empirical investigation". Journal of Development Economics, 4, 1 (3): 49-53.

- $\quad$ Pritchett, L., 1996." Measuring outward orientation in LDCs: Can it be done?", Journal of Development Economics, 49(2), 307-335.

- $\quad$ Ram, R., 1985. "Exports and economic growth: Some additional evidence". Economic Development and Cultural Change, 33, 2 (1): 415-25.

- Sheehey, E. J., 1993. "Exports as a factor of production: A consistency test. World Development", 21, 1 (1): 155-60.

- $\quad$ Sims, C.A., 1972. "Money, income and causality". American Economic Review, 62(9), 540-552. 